\title{
Relación entre conocimientos, actitudes, hábitos de salud bucodental y nivel socioeconómico en adultos de la Ciudad de Corrientes; Argentina
}

Relationship between oral health knowledge, behavior and habits, and socioeconomic level in adults in the City of Corrientes, Argentina
Relação entre conhecimentos, atitudes, hábitos de saúde buco-dental e nível socioeconômico em adultos da Cidade de Corrientes; Argentina
Fecha de Recepción

03 de marzo de 2017
Aceptado para su publicación

14 de abril de 2017

\section{María Silvina Dho}

Autora

Dra. Marta L. Schufer Directora

Carrera de Doctorado de la Universidad Nacional del Nordeste en Odontología

$\left(I^{\circ}\right.$ Cohorte)
Resumen

Se realizó un estudio transversal de base poblacional para analizar los conocimientos, actitudes y hábitos de salud bucodental y su relación con el nivel socioeconómico en $38 \mathrm{I}$ individuos de 35 a 44 años que viven en la Ciudad de Corrientes.

A partir de la literatura científica, se diseñó un instrumento de encuesta para la recolección de la información. Se examinaron la validez y fiabilidad de los constructos. Se capacitaron a encuestadores con el método simulación de roles. Se realizó una prueba piloto que permitió mejorar la redacción de las preguntas para su mayor comprensión y análisis posteriores.

Se aplicó un diseño muestral aleatorio simple para la selección de las viviendas a encuestar, que se complementó con un muestreo no probabilístico por cuotas para la selección de los individuos a entrevistar a partir de los datos proporcionados por el censo de población y vivienda 2010.

Los resultados indican que las personas de nivel socioeconómico medio-bajo presentan un nivel significativamente menor de conocimientos de salud bucodental que el resto de los grupos de estudio. Los individuos de nivel socioeconómico más bajo presentan actitudes de salud bucodental menos favorables, en particular en lo que se refiere a la actitud frente al dolor dental y a los motivos por los cuales se consulta al odontólogo; y presentan hábitos menos adecuados 
REVISTA FACULTAD DE ODONTOLOGÍA

ISSN No 1668-7280 - Vol. X No 1 - 2017

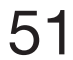

RESUMEN DE TESIS

Relación entre conocimientos, actitudes, hábitos de salud bucodental y nivel

socioeconómico en adultos de la Ciudad de

Corrientes; Argentina de regularidad con la que se renueva el cepillo dental, uso diario de hilo dental y regularidad de la consulta odontológica.

Los resultados de este trabajo pueden ser considerados como un recurso importante para diseñar estrategias de intervención que contemplen los determinantes socioculturales del proceso salud-enfermedad.

\section{Abstract}

A population-based cross sectional study was carried out in order to analyze oral health knowledge, behavior and habits, and their relationship with socioeconomic level among 38I individuals between 35 and 44 years old living in the City of Corrientes.

A survey instrument to collect information was designed on the basis of scientific literature. The validity and reliability of the constructs were examined. Survey takers were trained following the roleplay simulation method. A pilot test was conducted to improve the wording of the questions and make them more understandable for individuals and easier to analyze afterwards for researchers.

The homes to be surveyed were selected using a simple random sample design which was complemented by a non-probabilistic quota sampling for the selection of the individuals to be interviewed using the data provided by the 2010 population and housing census.

The results indicate that people from a medium-low socioeconomic level have an oral health knowledge level significantly lower than that of the rest of the study groups. Individuals from a lower socioeconomic level show behaviors less favorable towards oral health, particularly as regards their behavior towards oral pain and the reasons for consulting with a dentist; and they show less appropriate habits as regards the toothbrush replacement frequency, daily use of dental floss, and dental care consultation frequency.

The results of the present study could be considered a significant resource to design intervention strategies that take into consideration the socio-cultural determinants of the health-disease process.

\section{Resumo}

Foi realizado um estudo transversal de base populacional para analisar os conhecimentos, atitudes e hábitos de saúde buco-dental e sua relação com o nível socioeconômico em 38I indivíduos de 35 a 44 anos que vivem na cidade de Corrientes.

A partir da literatura científica, projetou-se um instrumento de pesquisa para a coleta de informação. Examinou-se a validade e fiabilidade dos construtos. Dos pesquisadores foram capacitados com o método de simulação de papéis. Foi realizada uma prova-piloto que permitiu melhorar a redação das perguntas para sua maior compreensão e análises posteriores.

Foi aplicado uma concepção de amostragem aleatório simples para a seleção das residências a serem pesquisadas, o qual foi complementado com uma amostragem não probabilística por quotas para a seleção dos indivíduos a serem entrevistados a partir dos dados proporcionados pelo censo de população e residências 2010.

Os resultados indicam que as pessoas de nível socioeconômico médio-baixo apresentam um nível significativamente menor de conhecimentos de saúde buco-dental que o restante dos grupos de estudo. Os indivíduos de nível socioeconômico mais baixo apresentam atitudes de saúde buco-dental menos favoráveis, em particular no que se refere à atitude ante à dor dental e aos motivos pelos quais se consulta o dentista; e apresentam hábitos menos adequados de regularidade com a que se renova a escova de dentes, uso diário de fio dentar e regularidade da consulta odontológica.

Os resultados desse trabalho podem ser considerados como um recurso importante para definir estratégias de intervenção que contemplem os determinantes socioculturais do processo de saúde-doença. 


\section{Referencias}

I. Frias AC, Mysuguti AH, Sanchez TP, Mantovani GL, Pestana SR. Social determinants and use of dental floss by 35-44-year-old adults. RGO 20I2; 60 (3): 32I-27.

2. Lian CW, Phing TS, Chan CS, Shin BC, Baharuddin LH, Che'Jalil ZB. Oral health knowledge, attitude and practice among secondary school students in Kuching, Sarawak. Arch Orofacial Sciences 2010; 5 (I): 9-16.

3. Macek MD, Manski MC, Schneiderman MT, Meakin SJ, Haynes D, Wells W et al. Knowledge of oral health issues among low-income Baltimore adults: a pilot study. J Dent Hyg. 20I I; 85 (I): 49-56.

4. Maltz M, Jardim JJ, Alves LS. Health promotion and dental caries. Braz Oral Res. 2010; 24 (I): 18-25.

5. Neamatollahi $\mathrm{H}$, Ebrahimi M. Oral health behavior and its determinants in a group of Iranian students. Indian J Dent Res. 20 I0; 2 I (I): 84-8.

6. Neamatollahi H, Ebrahimi M, Talebi M, Ardabili $\mathrm{MH}$, Kondori K. Major differences in oral health knowledge and behavior in a group of Iranian pre-university students: a cross-sectional study. J Oral Sci. 201 I; 53 (2): I77-84.

7. Tseveenjav B, Suominen-Taipale L, Varsio S, Hausen H, Knuuttila M, Vehkalahti MM. Patterns of oral cleaning habits and use of fluoride among dentate adults in Finland. Oral Health Prev Dent. 2010; 8 (3): 287-94.

8. Uysal S, Alev F, Yamalik N, Etikan I. Unmet Need for Education by Professionals and Inconsistency in Knowledge and Behavior of Dental Patients. NY State Dent J 2010; 76 (3): |6-2|.

9. Yildiz S, Dogan B. Self reported dental health attitudes and behaviour of dental students in Turkey. Eur J Dent. 20 I I; 5 (3): 253-9. 